\title{
Legislação e Jurisprudência (")
}

(De Janeiro a Junho de 1974)

\section{ACUMULAÇÃO}

- O Decreto-Lei n. $465 / 69$ só permite que se conte o tempo de serviço em que o funcionário, que acumula, esteve afastado para exercer o outro em Regime de Tempo Integral e Dedicação Exclusiva, para fins de aposentadoria.

Processo $n \cdot 6.429 / 73$ (COLEPE)

Diário Oficial de 19-2-74, pág. 1.929

\section{AFASTAMENTO}

- Dispõe sobre viagens ao exterior, a serviço ou com o fim de aperfeiçoamento sem nomeação ou designação, e dá outras providências. (Revoga os Decretos n.'s 61.775/67 e 67.494/70).

Decreto n. 74.143 , de $4 / 6 / 74$

Diário Oficial de $4 / 6 / 74$, capa

Retificado no Diário Oficial de $14 / 6 / 74$

- Faz recomendações quanto a viagens ao exterior de funcionários ou empregądos de todos os escalões da administração direta e indireta bem como das Fundações sob supervisão ministerial.

Circular PR - n. 3 , de $5 / 6 / 74$

Diário Oficial de 5/6/74, pág. 6.423.

- Indica os requisitos a serem preenchidos nos processos de afastamento com o fim de aperfeiçoamento no exterior, sem nomeação ou designação (Decreto n. $74.143 / 74$ ).

Portaria n. 129 , de $6 / 6 / 74$, do DG-DASP

Diário Oficial de $7 / 6 / 74$, pág. 6.537

\footnotetext{
- FONTE : Núcleo de Armazenamento de Informaçōes do Centro de Documentaçăo e Informática do DASP
} 


\section{- Declara :}

a) autorização de afastamento para Ministério ou Orgão diretamente subordinado à Presidência da República abrange qualquer afastamento de servidores da administração direta, seja qual for sua natureza jurídica, exceto quando se tratar da Presidência da República;

b) aprova o modelo de portaria a ser adotado no caso de exoneração a pedido.

Portaria n: 132, de 12/6/74, do DG-DASP

Diário Oficial de $14 / 6 / 74$, pág. 6.731

- Afastamento de servidor, não estável, para exercício de mandato legislatitivo. Interrupção do vínculo empregatício. O retorno será considerado nova admissão, não se aplicando os benefícios das Leis $3.967 / 61$ e 4.069/62, se, na data da entrada em vigor desses diplomas legais, ocorrera tal afastamento.

Processo $n \cdot{ }^{\circ} 792 / 72$ (Consultoria Jurídica do DASP)

D. O. 28-1-74, pág. 992 .

- Afastamento do País de servidores públicos federais para trabalhar junto a Organizaçōes Internacionais com as quais coopere o Brasil. O Decreto-lel n. 9.538/46, que disciplina o assunto, ainda em vigor. Considerações.

Processo $n \cdot 00.362 / 74$ (COLEPE-DASP)

Diário Oficial de $19-2-74$, pág. 1.928

\section{AJUDA DE CUSTO}

- Recomenda sejam observados quanto à concessão de diárias e ajuda de custo os procedimentos que menciona.

Circular da P.R., n. 6 , de $21 / 6 / 74$

Diário Oficial de $21 / 6 / 74$, pág. 6.936

- A Ajuda de Custo e as Diárias a título de auxílio previstas no Decreto $\mathrm{n}$. $807 / 62$, não são acumuláveis com a ajuda de custo e muito menos com as diárias de que trata a Lei $n \cdot 1.711 / 52$.

\section{Processo $n \cdot 30.996 / 73-G B$ (COLEPE-DASP) \\ Diário Oficial de $21 / 2 / 74$, pág. 2.057}

R. Serv. públ., Brasilia, 109 (3) Jul./set. 1974 
- A indenização pela transferência de exercício para Brasília regula-se pelo Decreto $807 / 62$, e suas alterações posteriores, não incidindo sobre a hipótese as normas que dispõem sobre a ajuda de custo no Estatuto dos Funcionários Públicos Civis da União.

Ofício-Parecer J-003-74 (Consultoria-Geral da República)

Diário Oficial de 9-5-74, pág. 5.306

\section{APERFEIÇOAMENTO}

- Dispõe sobre o Subsistema de Aperfeiçoamento do Pessoal Civil da Administração Federal $\Theta$ dá outras providências.

Decreto n. 73.421 , de $4 / 1 / 74$

Diário Oficial de $7 / 1 / 74$, pág. 131

- Regulamenta a Lei n. 5.833/72, que instituiu no Ministtério das Minas e Energia o Plano de Formação e Aperfeiçoamento do Pessoal de Nivel Superior" - PLANFAP, e dá outras providências.

Decreto $\mathrm{n} \cdot 73.594$, de $8 / 2 / 74$

Diário Oficial de $8 / 2 / 74$, capa

- Dispõe sobre viagens ao exterior, a serviço ou com o fim de aperfeiçoamento sem nomeação ou designação, e dá outras providências. (Revoga os Decretos n.`s 61.775/67 e 67.494/70).

Decreto n. 74.143 , de $4 / 6 / 74$

Diário Oficial de $4 / 6 / 74$, capa

\section{APOSENTADORIA}

- Aplicação do Plano de Classificação de Cargos de que trata a Lei n. $5.645 / 70$ aos servidores aposentados.

Decreto-lei n.: 1.325/74

Diário Oficial de 29/4/74

- Dispõe sobre a disponibilidade e aposentadoria dos membros da Magistratura Federal e dá outras providências.

Lei n. 6.044 , de 14/5/74

Diário Oficial de $15 / 5 / 74$, capa

R. Serv. públ., Brasília, 109 (3) jul./set. 1974 
- As leis ordinárias que estabeleceram exceções referentes ao limite de idade para aposentadoria do funcionário público, continuam em vigor até que lei nova as revogue tácita ou expressamente, regulando a matéria por inteiro.

Parecer 1-269/74 (Consultoria-Geral da República).

Diário Oficial de $1 / 3 / 74$, pág. 2.267 - Alterado pelo Parecer L-006/74 - Ver adiante.

- Tempo de serviço gratuito. Não é computável para aposentadoria.

Ofício-Parecer 1-261/74 (Consultoria-Geral da República)

Diário Oficial de 28-2-74, pág. 2.214

Não vigência das normas especiais, com redução de tempo de serviço e li. mite de idade, constantes de leis ordinárias anteriores à Constituição de 1969, modificando a orientação antecedente.

Parecer n. L-006/74 (Consultoria-Geral da República)

Diário Oficial de $7 / 6 / 74$, pág. 6.529

(Republicado no Diário Oficial de $12 / 7 / 74$, pp. $7.795 / 7.796$ ).

- A transformação de função gratificada em cargo em comissão guardando as mesmas características. Contagem de tempo. A continuidade de exercício após a transformação assegura ao ocupante a contagem do tempo anterior para efeito de aposentadoria, nos termos do art. 180 do Estatuto dos Funcionários Públicos, com as vantagens do cargo em comissão em que aquela se transformou.

Parecer 595/74 (Consultoria Juridica do DASP)

Diário Oficial de $26 / 3 / 74$, pág. 3.370

- Funcionário exonerado durante o estágio probatório, por alienação mental. Reintegração e aposentadoria. Em casos dessa espécie, entende-se que deve ser reintegrado o ex-servidor e providenciada sua aposentadoria, nos termos do art. 178, item III, da Lei n. $1.711 / 52$.

\section{Processo n: 6.508/73 (COLEPE-DASP) \\ Diário Oficial de $5 / 2 / 74$, capa}

- O Decreto-Lei n. 465/69 só permite que se conte o tempo de serviço em que o funcionário, que acumula, esteve afastado para exercer o outro em Regime de Tempo Integral e Dedicação Exclusiva, para fins de aposentadoria.

Processo $n . .^{\circ} 6.429 / 73$ (COLEPE-DASP)

Diário Oficial de $19 / 2 / 74$, pág. 1.929

R. Serv. públ., Brasília, 109 (3) jul./set. 1974 
- Expede, em aditamento à Portaria n. $94 / 74$, publicada no Diário Oficial de $13 / 5 / 74$, os modelos de Portaria de concessão de aposentadoria, a pedido, para funcionários dos sexos masculino e feminino.

Portaria n. 103 , de $16 / 5 / 74$ (DG-DASP)

Diário Oficial de $21 / 5 / 74$, pág. 5.779

\section{APROVEITAMENTO}

- O dar-se nova redação a texto de lei (no caso, a 5.060/66, para tornar efetivo o aproveitamento que a lei determina seja interino) é matéria de conveniência e oportunidade, a juizo exclusivo da administração.

Ofício-Parecer 1-260/74 (Consultoria-Geral da República)

Diário Oficial de 22/2/74, pág. 2.107

- Aproveitamento de servidor público em disponibilidade que fol condenado à pena de 6 meses de detenção que foi suspensa pelo prazo de 2 anos. O funcionário público inativo (aposentado ou em disponibilidade), que sofra condenação a pena privativa de liberdade ou seja submetido a medida de segurança detentiva, não poderá, enquanto recolhido a prisão ou a casa de custódia e tratamento, reverter ou ser aproveitado. Beneficiado, entretanto, pela suspensão condicional da pena ou restituído, por qualquer meio lícito, a liberdade, nada impedo o respectivo retorno à atividade desde que, obviamente, satisfaça como qualquer outro, os requisitos normalmente exigidos para tanto.

Processo n: $7.762 / 73$ (COLEPE-DASP)

Diário Oficial de $21 / 2 / 74$, pág. 2.057

- Instruções Normativas, no interesse da uniformidade, na execuçăo dos atos de aproveitamento delegados no Decreto n. 73.987 , de 1974, relativamente a :

I - Requisitos a serem preenchidos nos processos referentes aos atos delegados;

II - Modelos de Portarias a serem adotados na expedição de atos delegados.

Portaria n.: 94, de $1 / 5 / 74$ (DG-DASP)

Diário Oficial de 13/5/74

Ver Portaria n. $103 / 74$ (DG-DASP)

Diário Oficial de 21/5/74 
- Aproveitamento de Ex-combatente no Serviço Público. Inteligência do art. 197, alínea b, da Constituição Federal, em vigor.

A circunstância de ser analfabeto o ex-combatente impede-lhe o provimento em cargo público em sentido estrito, por força do art. 22, n. III, do Estatuto dos Funcionários, não elidido pela preceituação constitucional, mas não the veda a admissão em função trabalhista, do momento em que para tal preenchimento não se exige estar o candidato no gozo dos direltos políticos.

\section{Processos n.s $3.492,3.811,3.838$ e $3.848 / 73$ (COLEPE-DASP)}

Diário Oficial de $28 / 1 / 74$, pág. 993

- O aproveitamento de Ex-combatente em cargo de carreira de Procurador do DNER, com invocação do art. 197, alínea b da Constituição Federal.

O aproveitamento ali permitido só dispensa a formalidade de prévia habilitação em concurso, sujeitando o candidato aos demais requisitos legais aplicáveis à investidura de que se trate.

Impondo a Lei $\mathrm{n} \cdot{ }^{\circ} 1.341 / 51$, incidente, quanto a esse aspecto, sobre os Procuradores Autárquicos Federais (Lei $\mathrm{n} .^{\circ} 2.123 / 53$, art. 1. "caput"), a idade máxima de 35 anos para ingresso na carreira por estranhos ao serviço público (art. $3 .^{\circ}$ caput") o pedido não tem condições de deferimento.

Processo n: 427/73 (Consultoria Jurídica do DASP) Diário Oficial de $29 / 3 / 74$, pág. 3.552

\section{AUMENTO DE VENCIMENTOS}

- Reajusta os vencimentos e salários dos servidores do Poder Executivo e dá outras providências.

Decreto-lel n: 1.313 , de 28/2/74

Diário Oficial de $28 / 2 / 74$, capa

- Reajusta os vencimentos e salários dos servidores da Secretaria-Geral do Tribunal de Contas da União e dá outras providências.

Decreto-lei n: 1.318, de 12/3/74

Diário Oficial de $13 / 3 / 74$, capa

Aprovado pelo Decreto Legislativo $n \cdot 32 / 74$

R. Serv. públ., Brasilia, 109 (3) jul./set. 1974 
- Reajusta os vencimentos dos servidores do Governo do Distrito Federal e dá outras providências.

Decreto-lei n. 1.319 , de $12 / 3 / 74$

Diário Oficial de $13 / 3 / 74$, capa

Aprovado pelo Decreto Legislativo $n .{ }^{\circ} 38 / 74$

- Reajusta os vencimentos e salários dos servidores dos Serviços Auxiliares do Tribunal de Contas do Distrito Federal, e dá outras providências.

Decreto-Lei n: 1.320, de 12/3/74

Diário Oficial de $13 / 3 / 74$, pág. 2.771

Aprovado pelo Decreto Legislativo n. $35 / 74$

- Concede aumento de vencimentos aos funcionários do Tribunal Superior Eleitoral e dos Tribunais Regionais Eleitorais e dá outras providências.

Decreto-lei n. 1.321 , de $13 / 3 / 74$

Diário Oficial de $13 / 3 / 74$, pág. 2.772

Retificado no Diário Oficial de $27 / 3 / 74$

Aprovado pelo Decreto Legislativo n. $37 / 74$

- Concede aumento de vencimentos e salários aos servidores das Secretarias do Superior Tribunal Militar e das Auditorias da Justiça Militar, e dá outras providências.

Decreto-lei n.: 1.324, de 16/4/74

Diário Oficial de $16 / 4 / 74$, capa

Aprovado pelo Decreto Legislativo $n$ : $44 / 74$

- Reajusta os vencimentos, proventos e salários dos servidores das Secretarias do Tribunal Federal de Recursos e do Conselho da Justiça Federal e dá outras providências.

Decreto-lei n: 1.326, de 30/4/74

Diário Oficial de $2 / 5 / 74$, pág. 5.037

Aprovado pelo Decreto Legislativo n. $48 / 74$

- Reajusta os vencimentos e salários da Justiça Federal de Primeira Instância e dá outras providências.

Decreto-Lei n. 1.327 , de $3 / 5 / 74$

Diário Oficial de $6 / 5 / 74$, capa

Aprovado pelo Decreto Legislativo n. ${ }^{\circ} 47 / 74$

R. Serv. públ., Brasilia, 109 (3) jul./set, 1974 
- Concede aumento de vencimentos e salários aos servidores da Secretaria e dos Serviços Auxiliares do Tribunal de Justiça do Distrito Federal.

Decreto-lei $n .{ }^{\circ} 1.332$, de $5 / 6 / 74$,

Diário Oficial de $6 / 6 / 74$, capa

- Reajusta os vencimentos e salários dos servidores das Secretarias dos Tribunais do Trabalho, e dá outras providências.

Decreto-Lei n: 1.333 , de 6/6/74

Diário Oficial de $7 / 6 / 74$, capa

- Aprova as tabelas de valores e cálculos de despesa de Administração de Pessoal do Serviço Civil do Poder Executivo, relativamente a níveis, símbolos, vencimentos e gratificações - adicional, de Tempo Integral, de Ser. viço Extraordinário e de Representação, assim como a descontos para o IPASE, que vigorarão a partir de $10^{\circ}$ de março de 1974 , ex-ví do que dispóe o artigo 13 do Decreto-lei n. $1.313 / 74$.

Portaria n. 27 , de $5 / 3 / 74$ (DG-DASP)

Diário Oficial de $11 / 3 / 74$, pág. 2.599

Retificada no Diário Oficial de $13 / 3 / 74$, pág. 2.807

\section{BRASILIA}

- A indenização pela transferência de exercício para Brasília regula-se pelo Decreto n. $807 / 62$, e suas alterações posteriores, não incidindo sobre a hipótese as normas que dispõem sobre ajuda de custo no Estatuto dos Funcionários Públicos Civis da União.

Ofício-Parecer J-003/74 (Consultoria-Geral da República) Diário Oficial de $9 / 5 / 74$, pág. 5.306

\section{CARGO EM COMISSÃO}

$5 \therefore$

- Transformação de função gratificada em cargo em comissão guardando as mesmas características. Contagem de Tempo. A continuidade de exercício após a transformação assegura ao ocupante a contagem do tempo anterior para efeito de aposentadoria, nos termos do art. 180 do Estatuto dos Funcionários, com as vantagens do cargo em comissão em que aquela se transformou.

Processo n. 595/74 (Consultoria Jurídica do DASP) Diário Oficial de $26 / 3 / 74$, pág. 3.370

R. Serv. públ., Brasilia, 109 (3) jul./set. 1974 


\section{CARROS OFICIAIS}

- Recomenda fiel observância dos preceitos legais e regulamentares que disciplinam o uso de carros oficiais.

Circular da P.R. n. ${ }^{\circ}$, de 10/6/74

Diário Oficial de $11 / 6 / 74$, pág. 6.634

\section{CLASSIFICAÇÃO DE CARGOS}

- Dispõe sobre o critério seletivo para inclusão de funcionários nos Grupos: Serviços Auxiliares, Polícia Federal e Tributação, Arrecadação e Fiscalização, e dá outras providências.

Decreto n. 73.988 , de 26/4/74

Diário Oficial de $26 / 4 / 74$, pág. 4.847

- Fixa em 40 (quarenta) horas semanais o Regime de Trabalho para os ocupantes de encargos integrantes dos Grupos - Outras Atividades de Nível Superior e Serviços Jurídicos.

Portaria n..$^{\circ}$ 2, de $15 / 3 / 74$ (DG-DASP)

Diário Oficial de $18 / 3 / 74$, pág. 2.994

- Dispõe sobre o Subsistema de Classificação e Retribuição de Cargos e Empregos do Pessoal Civil da Administração Federal, e dá outras providências.

Decreto $\mathrm{n} .{ }^{\circ} 73.599$, de $8 / 2 / 74$

Diário Oficial de $8 / 2 / 74$, pág. 1.507

\section{CONDENAÇÃO JUDICIAL}

- O funcionário público inativo (aposentado ou em disponibilidade), que sofra condenação a pena privativa de liberdade ou seja submetido a medida de segurança detentiva, não poderá, enquanto recolhido a prisão ou a casa de custódia e tratamento, reverter ou ser aproveitado. Beneficiado, entretanto, pela suspensão condicional da pena ou restituído, por qualquer meio lícito, a liberdade, nada impede o respectivo retorno à atividade desde que, obviamente, satisfaça como qualquer outro, os requisitos normalmente exigidos para tanto.

Processo $n .^{\circ} 7.762 / 73$ (COLEPE-DASP)

Diário Oficial de 21/2/74; pág. 2.057

R. Serv. públ., Brasília, 109 (3) Jul./set. 1974 


\section{CONGRESSOS}

- Tendo em vista as normas sobre dispensa de ponto estabelecidas no Decreto n. $61.998 / 67$, reitera a recomendação contida na Circular n. 6 , de $7 / 11 / 69$.

Circular PR n: 7 , de $24 / 6 / 74$

Diário Oficial de $28 / 6 / 74$, pág. 7.209

\section{CONSELHO DA JUSTIÇA FEDERAL}

- Reajusta os vencimentos, proventos e salários dos servidores das Secretarias do Tribunal Federal de Recursos e do Conselho da Justiça Federal e dá outras providências.

Decreto-Lei n. 1.326 , de $30 / 4 / 74$

Diário Oficial de $2 / 5 / 74$, pág. 5.037

Aprovado pelo Decreto Legislativo $n .^{\circ} 48 / 74$

\section{CONSELHO DE DESENVOLVIMENTO ECONOMMICO}

- Dispõe sobre a criação, na Presidência da República, do Conselho de Desenvolvimento Econômico e da Secretaria de Planejamento, sobre o desdobramento do Ministério do Trabalho e Previdência Social e dá outras providências (Revoga o item I do artigo 199 do Dec.-Lei n. 200/67).

Lei $n$. $^{\circ} 6.036$, de $1 / 5 / 74$

Diário Oficial de $2 / 5 / 74$, pág. 5.036

\section{CONSELHO NACIONAL DE PÓS-GRADUAÇÃo}

— Institui o Conselho Nacional de Pós-Graduação e dá outras providências.

Decreto n: 73.411 , de $4 / 1 / 74$

Diário Oficial de $7 / 1 / 74$, capa

\section{CORREÇÃO MONETÁRIA}

- Venda de imóveis. Sua aplicação com base nas leis números $4.380 / 64$, $4.864 / 65$ e $5.049 / 66$.

Ofício-Parecer n. 1-272/74 (Consultoria-Geral da República)

Diário Oficial de 20/2/74, pág. 1.993

R. Serv. públ., Brasília, 109 (3) Jul./set. 1974 


\section{CUSTAS}

- Lispõe sobre o Regimento de Custas da Justiça Federal

Lei n. 6.032 , de $30 / 4 / 74$

Diário Oficial de $2 / 5 / 74$, pág. 5.030

\section{DECISÃO JUDICIAL}

- A revisão administrativa de processo não se constitui em meio hábil para reformar-se decisão judicial, proferida sobre o mesmo fato.

Oficio-Parecer n.: 1-262/74 (Consultoria-Geral da República)

Diário Oficial de $28 / 2 / 74$, pág. 2.214

- Dispõe sobre a alteração da orientação administrativa em virtude de de. cisões judiciais e dá outras providências.

Decreto n: 73.529 , de $21 / 1 / 74$

Diário Oficial de $22 / 1 / 74$, pág. 701

Republicado no Diário Oficial de $24 / 1 / 74$

\section{DELEGAÇÃO DE COMPETENCIA}

- Delegação de competência relativamente aos servidores civis da União:

* aos Ministros de Estado, ao Diretor-Geral do DASP e, no tocante aos demais órgãos diretamente subordinados à Presidência da República, ao Ministro Extraordinário para Assuntos do Gabinete Civil:

a) nomeação para cargo de provimento efetivo, exceto os integrantes dos Grupos: Outras Atividades de Nivel Superior (NS-900), Serviços Jurídi$\cos (\mathrm{SJ}-1.100)$. Tributação, Arrecadação e Fiscalização (TAF-600), Pesquisa Científica e Tecnológica (PCT-200) e Diplomacia (D-300).

b) nomeação por acesso;

c) promoção;

d) aproveitamento de servidor no âmbito do mesmo Ministério;

e) reversão;

f) transferência de funcionário, no âmbito do mesmo Ministério;

g) exoneração a pedido;

h) aposentadoria. 
* ao Diretor-Geral do Departamento Administrativo do Pessoal Civil (DASP):

a) transferência de funcionário de um para outro Ministério ou órgão diretamente subordinado à Presidência da República;

b) agregação;

c) autorização de afastamento para exercício em repartição de outro Minis. tério ou órgão diretamente subordinado à Presidência da República;

d) redistribuição de pessoal;

e) aproveitamento de servidor em Ministério diferente do de sua lotação.

Decreto n. 73.987 , de 24-4-74

Diário Oficial de $29 / 4 / 74$, pág. 4.926

- Instruções Normativas, no interesse da uniformidade, na execução dos atos delegados no Decreto $n .73 .987 / 74$, relativamente a:

I - Requisitos a serem preenchidos nos processos referentes aos atos delegados;

II - Modelos de Portarias a serem adotados na expedição de atos delega. dos.

Portaria $n .^{\circ}$ 94, de 1-5-74 (DG-DASP)

Diário Oficial de 13-5-74

(Ver Portaria n. $103 / 74$, DG-DASP, Diário Oficial de $21 / 5 / 74$ ).

\section{DELEGACIA DO TESOURO BRASILEIRO NO EXTERIOR}

- Extinção.

Decreto $n \cdot 74.175$, de $12 / 6 / 74$

Diário Oficial de $14 / 6 / 74$, pág. 6.728

\section{DIARIAS}

- A ajuda de custo e as diárias a título de auxílio previstas no Decreto n. $807 / 62$, não são acumuláveis com a ajuda de custo e muito menos com as diárias de que trata a Lei $\mathrm{n} .^{\circ} 1.711 / 52$.

\section{Processo n. 30.996/73-GB (COLEPE-DASP)}

Diário Oficial de 21/2/74, pág. 2.057

R. Serv. públ., Brasília, 109 (3) jul./set. 1974 
- Recomenda sejam observados quanto a concessão de diárias e ajuda de custo os procedimentos que menciona.

Circular PR n. 6, de 21/6/74

Diário Oficial de $21 / 6 / 74$, pág. 6.936

\section{DIREITO DE RETORNO (Acre)}

Dá nova redação aos artigos $10^{\circ}$ e $2 .^{\circ}$ da Lei n. $5.506 / 68$, que concedeu aos funcionários do extinto Território do Acre o direito de retorno aos serviços da União.

Lei n. 6.047 , de $16 / 5 / 74$

Diário Oficial de $17 / 5 / 74$, capa

\section{DIREITOS E VANTAGENS}

— Recomendações Presidenciais :

a) nenhum ato relativo a direitos e vantagens de pessoal seja expedido sem expressa fundamentação quer em norma legal ou regulamentar, quer em Parecer da Consultoria-Geral da República ou do Órgẳo Central do Sistema de Pessoal Civil (DASP);

b) os casos ainda năo disciplinados deverão ser submetidos ao DASP para a competente disciplinação; e

c) os Órgãos Setoriais do Sistema de Pessoal Civil deverão assistir, supervisionar e controlar a execução das atividades específicas dos órgãos Seccionais, além de difundir a orientação recebida do Órgão Central do SIPEC.

Circular da PR n: 01, de $7 / 5 / 74$

Diário Oficial de $8 / 5 / 74$, pág. 5.242

\section{DISPENSA DE PONTO}

- Tendo em vista as normas sobre dispensa de ponto estabelecidas no Decreto $n: 61.998 / 67$, reitera a recomendaçăo contida na Circular $n{ }^{\circ} 6$, de $7 / 11 / 69$.

Circular n. 7 , de $24 / 6 / 74$ (P.R.)

Diário Oficial de $28 / 6 / 74$, pág. 7.209 


\section{DISPONIBILIDADE}

- Dispõe sobre a disponibilidade e aposentadoria dos membros da Magistratura Federal e dá outras providências.

Lei n. 6.044 , de $14 / 5 / 74$

Diário Oficial de $15 / 5 / 74$, capa

\section{ECONOMISTA}

- Altera dispositivos da Lei $n{ }^{\circ} 1.411 / 51$, que dispõe sobre a Profissão de Economista; atualiza os valores das unidades, taxas e multas, subordinando-as a percentuais do maior salário mínimo, e altera a denominação dos Conselhos Federal e Regionais.

Lei n. 6.021 , de $3 / 1 / 74$, Diário Oficial de $6 / 3 / 74$

\section{ENQUADRAMENTO}

- Enquadramento com base na Lei n. 4.069/62. Transformado o recurso em proposta da administração, não está vedada a apreciação do mérito, desde que não tenha ocorrido prescrição.

Processo $n .0^{\circ} 3.125 / 72$ (Consultoria Jurídica do DASP)

Diário Oficial de $14 / 2 / 74$, pág. 1.710

- Proposta de retificação de enquadramentos irregulares decorrentes do Decreto $n$. $^{\circ}$ 54.389/64. Impossibilidade, pela prescrição, consolidando-se sltuações de fato, que se converteram em situações de direito, em alguns casos contra e em outros a favor dos servidores.

Processo $n \cdot{ }^{\circ} 225 / 74$ (Consultoria Jurídica do DASP)

Diário Oficial de $14 / 2 / 74$ - pág. 1.711

- Recurso com base na Lei n. 3.967/61. Não cabimento, em face do parágrafo único do art. $4 .^{\circ}$ do Decreto-lei $n .^{\circ} 625 / 69$. As revisőes de enquadramentos decorrentes das Leis $3.967 / 61$ e $4.069 / 62$, só podem ocorrer "exofficio", e se não houver ocorrido prescrição qüinqüenal.

Processo $n 0^{\circ} 3.940 / 73$ (Consultoria Jurídica do DASP) Diário Oficial de $14 / 2 / 74$, pág. 1.711

R. Serv. públ., Brasília, 109 (3) Jul./set. 1974 


\section{ESTABILIDADE}

- Regentes interinos de cátedra vaga e com mais de 5 anos de serviço público à data da promulgação da Constituição de 1967, fazem jus à estabili. dade prevista em seu art. 177 , parágrafo $2 .^{\circ}$

Ofício-Parecer 1-264/74 (Consultoria-Geral da República)

Diário Oficial de 22/2/74, pág. 2.108

\section{ESTADO-MAIOR DAS FORÇAS ARMADAS}

- Chefés do Gabinete Militar, Estado-Maior das Forças Armadas e Serviço Nacional de Informações. Natureza dos Cargos. Exame de situação básica. Situação em face da condição nova de Ministro de Estado conferida pela Lei $n .^{\circ} 6.036 / 74$.

Ofício-Parecer L-008/74 (Consultoria-Geral da República).

Diário Oficial de $7 / 6 / 74$, pág. 6.531

\section{ESTÁGIO PROBATÓRIO}

- Funcionário exonerado durante o estágio probatório, por alienação mental. Reintegração e aposentadoria.

Em casos dessa espécie, entende-se que deve ser reintegrado o ex-servidor e providenciada sua aposentadoria, nos termos do artigo 178 , item III, da Lei $n .^{\circ} 1.711 / 52$.

\section{Processo $n \circ 6.508 / 73$ (COLEPE/DASP) \\ Diário Oficial de $5 / 2 / 74$, capa}

\section{EX-COMBATENTE}

- Aproveitamento de Ex-combatente em cargo de carreira de Procurador do DNER, com invocação do artigo 197, alínea b, da Constituição Federal.

O aproveitamento ali permitido só dispensa a formalidade de prévia habilitação em concurso, sujeitando o candidato aos demais requisitos legais aplicáveis à investidura de que se trate. Impondo a Lei n. 1.341/51, incidente, quanto a esse aspecto, sobre os Procuradores Autárquicos Federais (Lei $n .2 .123 / 53$, art. 1. " "caput"), a idade máxima de 35 anos para ingresso na carreira por estranhos ao serviço público (art. $3 .^{\circ}$ "caput") o pedido não tem condiçōes de deferimento.

Processo n. $427 / 73$ (Consultoria Jurídica do DASP)

Diário Oficial de 29/3/74, pág. 3.552 
- Aproveitamento de Ex-combatente, analfabeto, no Serviço Público. Inteligência do art. 197, alínea b, da Constituição Federal, em vigor.

A circunstância de ser analfabeto o Ex-combatente impede-lhe o provimento em cargo público em sentido estrito, por força do art. $22, \mathrm{n}$. III, do Estatuto dos Funcionários, não elidido pela preceituação constitucional, mas não lhe veda a admissão em função trabalhista, do momento em que para tal preenchimento não se exige estar o candidato no gozo dos direitos politicos.

Processos n.`s 3.492, 3.811, 3.838 e $3.848 / 73$ (Consultoria Jurídica do DASP), Diário Oficial de $28 / 1 / 74$, pág. 993

\section{EXEECUÇAO ORÇAMENTARIA}

- Estabelece normas de execução orçamentária, define a programaçăo financeira do Tesouro Nacional no exercício de 1974 e dá outras providências.

Decreto n. 73.653 , de 15/2/74

Diário Oficial de $15 / 2 / 74$, pág. 1.758

Retificado no Dlário Oficial de $28 / 2 / 74$

\section{EXONERAĢOO}

- Declara :

a) afastamento (autorização de) para Ministério ou Orgão diretamente subordinado à Presidência da República abrange qualquer afastamento de servidores da administração direta, seja qual for sua natureza jurídica, exceto quando se tratar da Presidência da República;

b) aprova o modelo de portaria a ser adotado no caso de exoneraçăo a pedido.

Portaria n: 132 , de 12/6/74 (DG-DASP)

Diário Oficial de $14 / 6 / 74$, pág. 6.731

- Funcionário exonerado durante o estágio probatório, por alienação mental. Reintegração e aposentadoria.

Em casos dessa espécie, entende-se que deve ser reintegrado o ex-servidor e providenciada sua aposentadoria, nos termos do art. 178 , item III, da Lel n. $1.711 / 52$.

\section{Processo n.*6.508/73 (COLEPE-DASP)}

Diário Oficial de $5 / 2 / 74$, capa

R. Serv. públ., Brasilia, 109 (3) jul./set. 1974 
- Instruções Normativas, no interesse da uniformidade, na execução dos atos delegados no Decreto $n .73 .987 / 74$, relativamente a:

1 - requisitos a serem preenchidos nos processos referentes aos atos delegados;

II - modelos de portarias a serem adotados na expedição de atos delegados.

Portaria n. 94 , de 1/5/74, (DG-DASP)

Diário Oficial de 13/5/74 (Ver Portaria 103/74, D.O. 21/5/74).

\section{EXPEDIENTE}

- Dispõe sobre a suspensăo do expediente nos órgãos da Administraçăo $\mathrm{Fe}$ deral Direta e Indireta pela ocorrência de feriado religioso.

Decreto n. 74.149 , de 6-6-74

Diário Oficial de 6-6-74, capa

EXTERIOR (Lei de Retribuição)

- Altera a Tabela II (Anexo II), do Decreto n. 71.733 , de 18 de janeiro de 1973, que regulamenta a Lei de Retribuição no Exterior.

Decreto n. 73.526 , de $21 / 1 / 74$

Diário Oficial de 22/1/74, pág. 701

- Dispõe sobre viagens ao exterior, a serviço ou com o fim de aperfeiçoamento sem nomeação ou designação, e dá outras providências. (Revoga os Decretos n. ${ }^{\circ}$ s $61.775 / 67$ e $67.494 / 70$ ).

Decreto n. 74.143 , de $4 / 6 / 74$

Diário Oficial de $4 / 6 / 74$, capa

Retificado no Diário Oficial de $14 / 6 / 74$

- Faz recomendações quanto a viagens ao exterior de funcionários ou empregados de todos os escalões da administração direta e indireta bem como das Fundações sob supervisão ministerial.

Circular PR n: 3 , de $5 / 6 / 74$

Diário Oficial de $5 / 6 / 74$, pág. 6.423

R. Serv. públ., Brasília, 109 (3) jul./set. 1974 


\section{FIRMA}

- Recomenda a observância da norma estabelecida no Decreto n. 63.166/68, pela qual foi dispensada a exigência de reconhecimento de firma, não se admitindo, pois, procedimento em contrário.

Círcular da PR n. 2 , de 10/5/74

Diário Oficial de $13 / 5 / 74$, pág. 5.444

\section{FUNÇĀO GRATIFICADA}

- A transformação de função gratificada em cargo em comissão guardando as mesmas características. Contagem de tempo.

A continuidade de exercício após a transformação assegura ao ocupante a contagem do tempo anterior para efeito de aposentadoria, nos termos do art. 180 do Estatuto dos Funcionários, com as vantagens do cargo em comissão em que aquela se transformou.

Processo n. 595/74 (Consultoria Jurídica do DASP)

Diário Oficial de $26 / 3 / 74$, pág. 3.370

\section{FUNCIONÁRIO AUTARQUICO}

- Recolhimento relativo aos servidores autárquicos sob regime estatutário. Interpretaçăo do art. 164, n. II, alínea a do Regulamento da Previdência Social.

A contribuição de Previdência Social, recolhida ao INPS, relativamente aos servidores autárquicos sob regime estatutário, a que se refere o dispositivo, inclusive os da antiga Administração do Porto do Rio de Janeiro, é calculada sobre o vencimento, e vantagens acessórias incorporáveis a este, as quais, no IPASE, são consideradas para o mesmo fim, quanto aos funcionários públicos civis da União.

Ofício-Parecer n. J-002/74 (Consultoria-Geral da República) Diário Oficial de $10 / 4 / 74$, pág. 4.077

\section{GABINETE MILITAR}

- Chefes do Gabinete Militar, Estado-Maior das Forças Armadas e Serviço Nacional de Informações. Natureza dos Cargos. Exame de situação bá. sica. Situação em face da condição nova de Ministro de Estado conferida pela Lei $n 0^{\circ} 6.036 / 74$. 
Ofício-Parecer L-008/74 (CGR)

Diário Oficial de $7 / 6 / 74$, pág. 6.531

\section{GOVERNO DO DISTRITO FEDERAL}

- Reajusta os vencimentos dos servidores do Governo do Distrito Federal e dá outras providências.

Decreto-Lei n. 1.319 , de $12 / 3 / 74$

Diário Oficial de $13 / 3 / 74$, capa

Aprovado pelo Decreto Legislativo n: $38 / 74$

\section{GRUPO - OUTRAS ATIVIDADES DE NIVEL SUPERIOR}

- Fixa em 40 (quarenta) horas semanais o regime de trabalho para os ocupantes de cargos integrantes dos Grupos - Outras Atividades de Nível Superior e Serviços Jurídicos.

Portaria n. 42 , de $15 / 3 / 74$, (DG-DASP)

Diário Oficial de $18 / 3 / 74$, pág. 2.994

\section{GRUPO - SERVIÇOS JURÍDICOS}

- Fixa em 40 (quarenta) horas semanais o regime de trabalho para os ocupantes de cargos integrantes dos Grupos - Outras Atividades de Nível Superior e Serviços Jurídicos.

Portaria n. 42 , de $15 / 3 / 74$, (DG-DASP)

Diário Oficial de $18 / 3 / 74$, pág. 2.994

\section{HORARIO}

- Fixa em 40 (quarenta) horas semanais o regime de trabalho para os ocupantes de cargos integrantes dos Grupos - Outras Atividades de Nível Superior e Serviços Jurídicos.

Portaria n..$^{42}$, de $15 / 3 / 74$ (DG-DASP)

Diário Oficial de $18 / 3 / 74$, pág. 2.994 


\section{INDENIZAÇÃO}

- A indenização pela transferência de exercício para Brasília regula-se pelo Decreto n. ${ }^{\circ} 807 / 62$, e suas alterações posteriores, não incidindo sobre a hipótese as normas que dispõem sobre ajuda de custo no Estatuto dos Funcionários Civis da União.

Ofício-Parecer J-003/74 (Consultoria-Geral da República)

Diário Oficial de $9 / 5 / 74$, pág. 5.306

\section{INTERINIDADE}

- Regentes interinos de cátedra vaga e com mais de 5 anos de serviço público à data da promulgação da Constituição de 1967, fazem jus à estabiiłdade prevista em seu artigo 177, parágrafo $2 .^{\circ}$

Ofício-Parecer 1-264/74 (Consultoria-Geral da República)

Diário Oficial de 22/2/74, pág. 2.108

\section{JUSTIÇA FEDERAL DE PRIMEIRA INSTÂNCIA}

- Reajusta os vencimentos e salários da Justiça Federal de Primeira Instância e dá outras providências.

Decreto-Lel n. 1.327 , de $3 / 5 / 74$

Diário Oficial de $6 / 5 / 74$, capa

Aprovado pelo Decreto Legislativo n. $47 / 74$

\section{JUSTIÇA MILITAR}

- Concede aumento de vencimentos e salários aos servidores das Secretarias do Superior Tribunal Militar e das Auditorias da Justiça Militar, e dá outras providências.

Decreto-Lei n: 1.324 , de $16 / 4 / 74$

Diário Oficial de $16 / 4 / 74$, capa

Aprovado pelo Decreto Legislativo $n \cdot{ }^{\circ} 44 / 74$

\section{LICENÇA}

- Licença para acompanhar o cônjuge: É necessário que o cônjuge movimentado "ex-officio" seja funcionário público (civil ou militar) salvo se eleito para o Congresso Nacional.

\section{Processo n. 404/74 (COLEPE-DASP) \\ Diário Oficial de $19 / 2 / 74$ - pág. 1.929}

R. Serv. públ., Brasília, 109 (3) jul./set. 1974 


\section{MAGISTÉRIO}

- Enquadramento. Carga Horária. Exigência não prevista em lei.

Ofício-Parecer 1-281/74 (Consultoria-Geral da República)

Diário Oficial de $13 / 3 / 74$, pág. 2.806

(Ver, também, Ofício-Parecer 153-H/65) .

\section{MAGISTRATURA FEDERAL}

- Dispõe sobre a disponibilidade e aposentadoria dos membros da Magistratura Federal e dá outras providências.

Lei n. 6.044 , de $14 / 5 / 74$

Diário Oficial de $15 / 5 / 74$, capa

\section{MANDATO LEGISLATIVO}

- Afastamento de servidor, não estável, para exercício de mandato legislatlvo. Interrupção do vínculo empregatício. O retorno será considerado nova admissão, não se aplicando os benefícios das leis n.`s 3.967/61 e 4.069/62 se, na data da entrada em vigor desses diplomas legais, ocorrera tal afastamento.

Processo n. $792 / 72$ (Consultoria Jurídica do DASP)

Diário Oficial de $28 / 1 / 74$, pág. 992

\section{MINISTÉRIO DA PREVIDENCIA E ASSISTENCIA SOCIAL}

- Dispõe sobre a criação, na Presidência da República, do Conselho de Desenvolvimento Econômico e da Secretaria de Planejamento, sobre o desdobramento do Ministério do Trabalho e Previdência Social e dá outras providências (Revoga o item I do artigo 199 do Decreto-Lei n. 200/67.

Lei n. 6.036 , de $1 / 5 / 74$

Dlário Oficial de $2 / 5 / 74$, pág. 5.036

- Dispõe sobre o desdobramento do extinto Ministério do Trabalho e Prevldência Social e a instalação do Ministério da Previdência e Assistência So. cial e dá outras providências.

Lei n. 6.062 , de $25 / 6 / 74$

Diário Oficial de $26 / 6 / 74$, capa

R. Serv. públ., Brasflia, 109 (3) Jul//set. 1974 
- Dispõe sobre a estrutura básica do Ministério da Previdência e Assistência Social e dá outras providências.

Decreto n. 74.254 , de $4 / 7 / 74$

Diário Oficial de $5 / 7 / 74$, pág. 7.446

\section{MINISTÉRIO DO TRABALHO}

- Desdobramento do atual Ministério do Trabalho e Previdência Social com a criação do Ministério da Previdência e Assistência Social.

Lei $\mathrm{n} \cdot{ }^{\circ} 6.036$, de $1 / 5 / 74$

Diário Oficial de $2 / 5 / 74$, pág. 5.036

\section{MINISTRO DE ESTADO}

- Chefes do Gabinete Militar, Estado-Maior das Forças Armadas e Serviço Nacional de Informações. Natureza dos cargos. Exame de situação básica. Situação em face da condição nova de Ministro de Estado conferida pela Lei $n .^{\circ} 6.036 / 74$.

\section{Ofício-Parecer L-008/74 (Consultoria-Geral da República)}

Diário Oficial de $7 / 6 / 74$, pág. 6.531

\section{MODELOS}

- Aprova o modelo de portaria a ser adotado no caso de exoneração a pedido.

Portaria $n .^{\circ} 132$, de $12 / 6 / 74$ (DG-DASP)

Diário Oficial de $14 / 6 / 74$, pág. 6.731

- Expede, em aditamento à Portaria n. 94/74, publicada no Diário Oficial de $13 / 5 / 74$, os modelos de portaria de concessão de aposentadoria, a pedido, para funcionários dos sexos: masculino e feminino.

Portaria $n \cdot 103$, de 16/5/74, (DG-DASP)

Diário Oficial de $21 / 5 / 74$, pág. 5.779

- Instruções Normativas, no interesse da uniformidade, na execuçã̃o dos atos delegados no Decreto $n .^{\circ} 73.987 / 74$, relativamente a :

1 - Requisitos a serem preenchidos nos processos referentes aos atos delegados;

R. Serv. públ., Brasília, 109 (3) jul./set. 1974 
II - Modelos de Portarias a serem adotados na expedição de atos delegados.

Portaria n. 94 , de $1 / 5 / 74$ (DG-DASP)

Diário Oficial de 13/5/74

(Ver Portaria $103 / 74$, D.O. de $21 / 5 / 74$ )

\section{MONTEPIO MILITAR}

- Contribuintes civis, sob o regime do Decreto-lei n. 9.798/46. Direitos as-

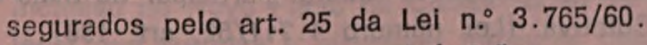

Critério de cálculo das contribuições.

Ofício-Parecer L-002/74 (Consultoria-Geral da República)

Diário Oficial de $15 / 5 / 74$, pág. 5.555

\section{NOMEAÇÃO}

- Instruções Normativas, no interesse da uniformidade, na execução dos atos delegados no Decreto $n$. $^{7} 73.987 / 74$, relativamente a:

1 - Requisitos a serem preenchidos nos processos referentes aos atos delegados;

II - Modelos de portarias a serem adotados na expedição de atos delegados.

Portaria n. 94, de $1 / 5 / 74$ (DG-DASP)

Diário Oficial de $15 / 5 / 74$, pág. 5.555

\section{OPÇÃO}

- Funcionários requisitados de Estados e Autarquias.

Inclusão no novo Plano de Classificação de Cargos. Necessidade de norma legal que autorize a alteraçăo funcional quanto ao Quadro a que pertença (Considerações).

Processo $\mathrm{s} / \mathrm{n}$ (COLEPE-DASP)

Diário Oficial de $12 / 2 / 74$, pág. 1.590

R. Serv. públ., Brasília, 109 (3) jul./set. 1974 


\section{ORGANIZAÇÕES INTERNACIONAIS}

- Afastamento de servidores públicos federais para trabalhar junto a Organizações Internacionais com as quais coopere o Brasil.

O Decreto-lei $n .^{\circ} 9.538 / 46$, que disciplina o assunto, ainda em vigor.

Processo $n:^{\circ}$ 00362/74 (COLEPE-DASP)

Diário Oficial de 19/2/74, pág. 1.928

\section{ÓRGAOS DE DELIBERAC̣Ão COLETIVA}

- Impossibilidade legal de o funcionário público federal participar de mais de um Órgão de Deliberação Coletiva (Lei número $1.711 / 52$, art. 190).

Ofício-Parecer 1-277/74 (Consultoria-Geral da República)

Diário Oficial de $13 / 3 / 74$, pág. 2.805

\section{ORIENTAÇÃO ADMINISTRATIVA}

- Dispõe sobre a alteração da orientação administrativa em virtude de de. cisões judiciais e dá outras providências.

Decreto n. 73.529 , de $21 / 1 / 74$

Diário Oficial de 22/1/74, pág. 701

Republicado no Diário Oficial de 24/1/74

\section{PENSIONISTAS (Pagamento)}

- Dispõe sobre a transferência para o INPS do encargo dos pagamentos da complementação da pensão especial instituída pela Lei $n$. $^{\circ} 3.738 / 60$ e do salário-família devidos pelo Tesouro Nacional às viúvas e dependentes de funcionários civis, pensionistas daquele instituto e dá outras providências.

Decreto $n \cdot 73.833$, de $13 / 3 / 74$

Diário Oficial de $13 / 3 / 74$, pág. 2.781

\section{PESSOAL EVENTUAL}

- Cobrança de contribuição previdenciária a servidores eventuais. E legítima a cobrança de contribuição previdenciária dos servidores públicos, ditos eventuais, contratados para prestação de serviços de caráter permanente, ainda, que remunerados contra-recibo, a partir da contratação, independenmente das alteraçőes decorrentes da Lel $n \cdot{ }^{\circ} 5.890 / 73$.

Ofício-Parecer 1-266/74 (Consultoria-Geral da República)

R. Serv. públ., Brasília, 109 (3) jul./set. 1974 


\section{PLANO DE CLASSIFICAÇÃO DE CARGOS}

- Dispõe sobre a aplicação do Plano de Classificação de Cargos de que trata a Lei $n$. 5.645/70, aos servidores aposentados, e dá outras providências (Revoga 0 art. 10 e parágrafos do Decreto-lei $n .^{\circ} 1.256 / 73$ ).

Decreto-lei n. 1.325 , de 26/4/74

Diário Oficial de 29/4/74, capa

Aprovado pelo Decreto Legislativo $45 / 74$,

Diário Oficial de 10/6/74

- Funcionários requisitados de Estados e Autarquias.

Inclusão no Novo Plano de Classificação de Cargos. Necessidade de norma legal que autorize a alteração funcional quanto ao Quadro a que pertença (Considerações).

Processo $\mathrm{s} / \mathrm{n}$ (COLEPE-DASP)

Diário Oficial de $12 / 2 / 74$, pág. 1.590

\section{PLANO DE FORMAÇÃO E APERFEIÇOAMENTO DO PESSOAL DE NIVEL SUPERIOR - PLANFAP (M.M.E.)}

- Regulamenta a Lei $n$. 5.833/72, que instituiu, no Ministério das Minas e Energia, o "Plano de Formação e Aperfeiçoamento do Pessoal de Nivel Superior" - PLANFAP, e dá outras providências.

Decreto $n \cdot 73.594$, de $8 / 2 / 74$

Diário Oficial de $8 / 2 / 74$, capa

\section{PODER EXECUTIVO}

- Reajusta os vencimentos e salários dos servidores do Poder Executivo e dá outras providências.

Decreto-lei n: 1.313 , de $28 / 2 / 74$

Diário Oficial de $28 / 2 / 74$, capa

Aprovado pelo Decreto Legislativo n. 29/74

(Tabelas publicadas no Diário Oficial de $13 / 3 / 74$, pág. 2.807)

\section{POLICIA DO DISTRITO FEDERAL}

- Dispõe sobre o Estatuto dos Policiais-Militares da Polícia do Distrito Federal e dá outras providências.

Lei n. 6.023 , de $3 / 1 / 74$

Diário Oficial de $4 / 1 / 74$, pág. 81

Retificado no Diário Oficial de $6 / 3 / 74$

R. Serv. públ., Brasília, 109 (3) jul./set. 1974 


\section{PÓS-GRADUAC̣ÃO}

- Institui o Conselho Nacional de Pós-Graduação e dá outras providências.

Decreto n.? 73.411 , de $4 / 1 / 74$

Diário Oficial de $7 / 1 / 74$, capa

\section{PRESCRIC̣ÃO}

- Enquadramento com base na Lei n. 4.069/62.

Transformado o recurso em proposta da administração, não está vedada a apreciação do mérito, desde que não tenha ocorrido prescrição.

\section{Processo $\mathrm{n}:$ 3.125/72 (Consultoria Jurídica do DASP)} Diário Oficial de $14 / 2 / 74$, pág. 1.710 - Proposta de retificação de enquadramentos irregulares decorrentes do De-
creto $n \cdot{ }^{\circ} 54.389 / 64$.

Impossibilidade, pela prescrição, consolidando-se situações de fato, que se converteram em situações de direito, em alguns casos contra e em outros a favor dos servidores.

Processo n.: 225/74 (Consultoria Jurídica do DASP)

Diário Oficial de $14 / 2 / 74$, pág. 1.711

- Recurso de enquadramento com base na Lei $n .^{\circ} 3.967 / 61$. Não cabimento, em face do parágrafo único do art. $4 .^{\circ}$ do Decreto-lei $n$. $625 / 69$.

As revisões de enquadramentos decorrentes das Leis n.'s 3.967, de 1961 e 4.069/62, só podem ocorrer "ex-officio", e se não houver ocorrido prescri-
ção qüinqüenal.

Processo $n: 3.940 / 73$ (Consultoria Jurídica do DASP) Diário Oficial de $14 / 2 / 74$, pág. 1.711

\section{PREVIDENCIA SOCIAL (Contribuição)}

- Recolhimento relativo aos servidores autáquicos sob regime estatutário. Interpretação do art. 164, n. II, alínea a do Regulamento da Previdência
Social. 
A contribuição de Previdência Social, recolhida ao INPS, relativamente aos servidores autárquicos sob regime estatutário, a que se refere o dispositivo, inclusive os da antiga APRJ, é calculada sobre o vencimento, e vantagens acessórias incorporáveis a este, as quais, no IPASE, são consideradas para o mesmo fim, quanto aos funcionários públicos civis da União.

Ofício-Parecer J-002/74 (Consultoria-Geral da República)

Diário Oficial de $10 / 4 / 74$, pág. 4.077

- Cobrança de contribuição previdenciária a servidores eventuais. É legítima a cobrança de contribuiçẫo previdenciária dos servidores públicos, ditos eventuais, contratados para prestação de serviços de caráter permanente, ainda que remunerados contra-recibo, a partir da contratação, independentemente das alterações decorrentes da Lei n. $5.890 / 73$.

Ofício-Parecer 1-266/74 (Consultoria-Geral da República) Diário Oficial de $28 / 2 / 74$, pág. 2.215

\section{PROCESSO ADMINISTRATIVO}

- Revisão Administrativa de processo. Decisão judicial. A revisão administra. tiva de processo não se constitui em meio hábil para reformar-se decisão judicial, proferida sobre o mesmo fato.

Ofício-Parecer 1-262/74 (Consultoria-Geral da República)

Diário Oficial de $28 / 2 / 74$, pág. 2.214

\section{PROGRAMA DE ASSISTENCIA AO TRABALHADOR RURAL}

- Aprova o Regulamento.

Decreto n. 73.617 , de $12 / 2 / 74$

Diário Oficial de 28/2/74

Retificado no Diário Oficial de $28 / 2 / 74$

\section{PROGRAMAÇÃO FINANCEIRA}

- Estabelece normas de execução orçamentária, define a programaçăo financeira do Tesouro Nacional, no exercício de 1974 e dá outras providências.

Decreto n. 73.653 , de $15 / 2 / 74$

Diário Oficial de $15 / 2 / 74$, pág. 1.758

Retificado no Diário Oficial de $28 / 2 / 74$

R. Serv. públ., Brasília, 109 (3) jul./set. 1974 


\section{PROMOC̣ÃO}

- Instruções Normativas, no interesse da uniformidade, na execução dos atos delegados no Decreto $n .^{\circ} 73.987 / 74$, relativamente a :

1 - Requisitos a serem preenchidos nos processos referentes aos atos delegados;

II - Modelos de portarias a serem adotados na expedição de atos delegados.

Portaria $n . \circ 94$, de $1 / 5 / 74$ (DG-DASP)

Diário Oficial de $13 / 5 / 74$

(Ver Portaria n. $103 / 74$, D. O. 21/5/74)

\section{READAPTAÇÃO}

- Readaptação no cargo de Consultor Jurídico, proposta antes da vigência da Leil $n$. 4.439/64.

Viabilidade. Considerações.

Ofício-Parecer 1-268/74 (Consultoria-Geral da República)
Diário Oficial de $1 / 3 / 74$, pág. 2.267

\section{RECONHECIMENTO DE FIRMAS}

- Recomenda a observância da norma estabelecida no Decreto n. $63.166 / 68$, pela qual foi dispensada a exigência de reconhecimento de firma, não se admitindo, pois, procedimento em contrário.

Circular PR n.: 2, de 10/5/74

Diário Oficial de $13 / 5 / 74$, pág. 5.444

\section{RECURSO}

- Enquadramento com base na Lei n. 4.069/62.

Transformado o recurso em proposta da administração, não está vedada a apreciaçăo do mérito, desde que não tenha ocorrido prescrição.

Processo $n: 3.125 / 72$ (Consultoria Jurídica do DASP)
Diário Oficial de $14 / 2 / 74$, pág. 1.710

R. Serv. públ., Brasilia, 109 (3) jul./set. 1974 
- Enquadramento. Recurso com base na Lei n. 3.967/61. Não cabimento, em face do parágrafo único do art. $4 i^{\circ}$ do Decreto-lei n. $625 / 69$. As revisões de enquadramentos decorrentes das Leis n. ${ }^{\circ}$ 3.967/61 e 4.069/62, só podem ocorrer "ex-officio" e se não houver ocorrido prescrição qüinqüenal.

Processo n. 3.940/73 (Consultoria-Geral da República)

Diário Oficial de $14 / 2 / 74$, pág. 1.711

\section{REDISTRIBUIÇÃO}

- Instruções Normativas, no interesse da uniformidade, na execução dos atos delegados no Decreto $n: 73.987 / 74$, relativamente a:

1 - Requisitos a serem preenchidos nos processos referentes aos atos delegados;

II - Modelos de portarias a serem adotados na expediçảo de atos delegados.

Portaria n: 94 , de $1 / 5 / 74$ (DG-DASP)

Diário Oficial de $13 / 5 / 74$

(Ver Portaria n. $103 / 74$, D.O. de $21 / 5 / 74$ ).

\section{REFORMA ADMINISTRATIVA}

- Dispõe sobre a criação, na Presidência da República, do Conselho de Desenvolvimento Econômico e da Secretaria de Planejamento, sobre o desdobramento do Ministério do Trabalho e Previdência Social e dá outras providências. (Revoga o item I do artigo 199 do Decreto-lei n.:200/67).

Lei $\mathrm{n} \cdot 6.036$, de $1 / 5 / 74$

Diário Oficial de $2 / 5 / 74$, pág. 5.036

- Institui o Conselho Nacional de Pós-Graduação e dá outras providências.

Decreto n. 73.411 , de $4 / 1 / 74$

Diário Oficial de $7 / 1 / 74$, capa

- Aplicação do artigo 566 da CLT em face das alterações decorrentes da Re-

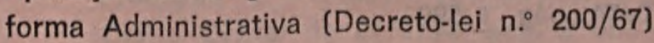




\title{
REGIME DE TRABALHO
}

- Fixa em 40 (quarenta) horas semanais o regime de trabalho para os ocupantes de cargos integrantes dos Grupos - Outras Atividades de Nivel Superior e Serviços Jurídicos.

Portaria n.: 42, de 15/3/74 (DG-DASP)

Diário Oficial de $18 / 3 / 74$, pág. 2.994

\section{REGULAMENTAÇÃO PROFISSIONAL}

- Altera dispositivos da Lei n. 1.411 , de 1951, que dispōe sobre a Profissão de Economista; atualiza os valores das anuidades, taxas e multas, subordinando-as a percentuais do maior salário-mínimo, e altera a denominação dos Conselhos Federal e Regionais.

Lei n. 6.021 , de $3 / 1 / 74$

Diário Oficial de $4 / 1 / 74$, pág. 74

Retificado no Diário Oficial de $6 / 3 / 74$

\section{REINTEGRAÇÃO}

- Funcionário exonerado durante o estágio probatório, por alienaçāo mental. Reintegração e Aposentadoria.

Em casos dessa espécie, entende-se que deve ser reintegrado o ex-servidor e providenciada sua aposentadoria, nos termos do art. 178, item III, da Lei n. $1.711 / 52$.

Processo n. $6.508 / 73$ (COLEPE-DASP, D.O. 5/2/74, capa)

\section{REQUISIÇÃO}

- Opção de funcionários requisitados de Estados e Autarquias. Inclusão no Novo Plano de Classificação de Cargos. Necessidade de norma legal que autorize a alteração funcional quanto ao Quadro a que pertença (Conside-
raços).

\author{
Processo $\mathrm{s} / \mathrm{n}$ (COLEPE-DASP) \\ Diário Oficial de $12 / 2 / 74$, pág. 1.590
}

R. Serv. públ., Brasília, 109 (3) jul./set. 1974 


\section{RETRIBUIÇÃO DE CARGOS}

- Dispõe sobre o Subsistema de Classificação e Retribuição de Cargos e Empregos do Pessoal Civil da Administração Federal, e dá outras providências.

Decreto n. 73.599 , de $8 / 2 / 74$

Diário Oficial de $8 / 2 / 74$, pág. 1.507

\section{RETRIBUIÇÃO NO EXTERIOR}

- Altera a Tabela II (Anexo II), do Decreto n. 71.733, de 18 de janeiro de 1973, que regulamenta a Lei de Retribuição no Exterior.

Decreto n. 73.526 , de $21 / 1 / 74$

Diário Oficial de $22 / 1 / 74$, pág. 701

\section{REVERSÃO}

- Instruções Normativas, no interesse da uniformidade, na execução dos atos delegados no Decreto n. $73.987 / 74$, relativamente a:

1 - Requisitos a serem preenchidos nos processos referentes aos atos delegados;

II - Modelos de portarias a serem adotados na expedição de atos delegados.

Portaria n. 94, de 1/5/74 (DG-DASP)

Diário Oficial de $13 / 5 / 74$

\section{REVERSÃO}

- Servidor público em disponibilidade que foi condenado à pena de 6 meses de detenção que foi suspensa pelo prazo de 2 anos. O funcionário público inativo (aposentado ou em disponibilidade) que sofra condenação a pena privativa de liberdade ou seja submetido a medida de segurança detentiva, não poderá, enquanto recolhido a prisão ou a casa de custódia e tratamento, reverter ou ser aproveitado. Beneficiado, entretanto, pela suspensão condicional da pena ou restituído, por qualquer meio lícito a liberdade, nada impede o respectivo retorno à atividade desde que, obviamente, satisfaça como qualquer outro, os requisitos normalmente exigidos para tanto.

Processo $n .^{\circ} 7.762 / 73$ (COLEPE-DASP)

Diário Oficial de $21 / 2 / 74$, pág. 2.057

R. Serv. públ., Brasília, 109 (3) jul./set. 1974 


\section{REVISÃO DE PROCESSO ADMINISTRATIVO}

- A revisão administrativa de processo não se constitui em meio hábil para reformar-se decisão judicial, proferida sobre o mesmo fato.

Ofício-Parecer 1-262/74 (Consultoria-Geral da República)

Diário Oficial de $28 / 2 / 74$, pág. 2.214

\section{SALÁRIO-FAMILIA}

- Formulação n. 173 da COLEPE-DASP. Pedido de revisão.

'Não há que confundir, para efeito de percepção de salário-familia, as expressões "sem economia própria" com "sem qualquer rendimento". Só tem economia própria quem, sem bens, percebe rendimento igual ou superior ao salário-mínimo. Já a inexistência de qualquer rendimento é condição muito mais restritiva, limitando-se ao valor do salário-família, e assim mesmo porque expressamente estatui a Lei (Lei n. ${ }^{\circ} 1.765 / 52$, art. II, parágrafo $1.0^{\circ}$.

Processo n: 1.926/72 (Consultoria Jurídica do DASP)

Diário Oficial de $25 / 4 / 74$, pág. 4.785

\section{SALARIO-MINIMO}

- Altera a Tabela de Salário-Mínimo aprovada pelo Decreto $n$. $^{\circ} \cdot 72.148 / 73$.

Decreto n. 73.995 , de $29 / 4 / 74$

Diário Oficial de $30 / 4 / 74$, pág. 4.966

\section{SECRETARIA DE PLANEJAMENTO - P.R.}

- Criaçăo

Lei $n: 6.036$, de $1 / 5 / 74$

Diário Oficial de $2 / 5 / 74$, pág. 5.036

\section{SERVIÇO GRATUITO}

- Cômputo de serviço gratuito. Năo é computável para aposentadoria.

Ofício-Parecer $1-261 / 74$ (Consultoria-Geral da República)
Diário Oficial de $28 / 2 / 74$, pág. 2.214

R. Serv. públ., Brasilia, 109 (3) jul./set. 1974 


\section{SERVIÇO NACIONAL. DE INFORMAÇÕES}

- Chefes do Gabinete Militar, Estado-Maior das Forças Armadas e Serviço Nacional de Informações. Natureza dos Cargos. Exame de situação básica. Situação em face da condição nova de Ministro de Estado conferida pela pela Lei $n .^{\circ} 6.036 / 74$.

Ofício-Parecer L-008/74 (Consultoria-Geral da República)

\section{SINDICALIZAÇÃO}

- Aplicação do art. 566 da CLT em face das alterações decorrentes da Reforma Administrativa (Decreto-Lei n. 200/67).

Ofício-Parecer 1-267/74 (Consultoria-Geral da República)

Diário Oficial de $21 / 2 / 74$, pág. 2.055

\section{SISTEMA MÉDICO-PERICIAL}

- Dispõe sobre o Sistema Médico-Pericial do Serviço Público Federal e dá outras providências.

Decreto n. 73.615 , de $11 / 2 / 74$

Diário Oficial de $12 / 2 / 74$, pág. 1.586

\section{SISTEMA DE PESSOAL (SIPEC)}

- Dispõe sobre o Subsistema de Aperfeiçoamento do Pessoal Civil da Administração Federal e dá outras providências.

Decreto $n \cdot 73.421$, de $4 / 1 / 74$

Diário Oficial de $7 / 1 / 74$, pág. 131

- Dispõe sobre o Subsistema de Classificação e Retribuição de Cargos e Empregos do Pessoal Civil da Administração Federal e dá outras providências.

Decreto $n \cdot 73.599$, de $8 / 2 / 74$

Diário Oficial de $8 / 2 / 74$, pág. 1.507

— Recomendações presidenciais :

a) nenhum ato relativo a direitos e vantagens de pessoal seja expedido sem expressa fundamentação quer em norma legal ou regulamentar.

R. Serv. públ., Brasília, 109 (3) jul./set. 1974 
quer em Parecer da Consultoria-Geral da República ou do Órgão Central do Sistema de Pessoal Civil (DASP);

b) os casos ainda não disciplinados deverão ser submetidos ao DASP para a competente disciplinação; e

c) Os Órgãos Setoriais do Sistema de Pessoal Civil deverão assistir, supervisionar e controlar a execução das atividades específicas dos Orgãos Seccionais, além de difundir a orientação recebida do Órgão Cen-
tral do SIPEC.

Circular da P.R. n. 01 , de $7 / 5 / 74$

Diário Oficial de $8 / 5 / 74$, pág. 5.242

\section{SITUAÇÃO DE FATO}

- Proposta de retificação de enquadramentos irregulares decorrentes do Decreto $n .^{\circ}$ 54.389/64.

Impossibilidade, pela prescrição, consolidando-se situações de fato, que se converteram em situações de direito, em alguns casos contra e em outros a favor dos servidores.

Processo $n .^{\circ} 225 / 74$ (Consultoria Jurídica do DASP)

Diário Oficial de $14 / 2 / 74$, pág. 1.711

\section{SUPERIOR TRIBUNAL MILITAR}

- Reajusta os vencimentos, proventos e salários dos servidores das Secretarias do Tribunal Federal de Recursos e do Conselho da Justiça Federal e
dá outras providências.

Decreto-Lei n. 1.326 , de $30 / 4 / 74$

Diário Oficial de $2 / 5 / 74$, pág. 5.037

\section{TABELAS}

- Aprova as tabelas de valores e cálculos de despesa de administração de pessoal do Serviço Civil do Poder Executivo, relativamente a níveis, símbolos, vencimentos e gratificações - adicional, de tempo integral, de serviço extraordinário e de representação, assim como a descontos para o IPASE, que vigorarão a partir de $10^{\circ}$ de março de 1974 , ex-vi do que dispõe o artigo
13 do Decreto-lei $n .^{\circ} 1.313 / 74$.

Portaria $n .^{\circ} 27$, de 5/3/74 (DG-DASP)

Diário Oficial de $11 / 3 / 74$, pág. 2.599

Retificado no Diário Oficial de $13 / 3 / 74$, pág. 2.807

R. Serv. públ., Brasilia, 109 (3) jul./set. 1974 


\section{TEMPO DE SERVIÇO}

- O Decreto-lei n. ${ }^{4} 465 / 69$ só permite que se conte o tempo de serviço em que o funcionário, que acumula, esteve afastado para exercer o outro em regime de tempo integral e dedicação exclusiva, para fins de aposentadoria.

Processo n. $6.429 / 73$ (COLEPE-DASP)

Diário Oficial de 19/2/74 - pág. 1.929

- Tempo de serviço gratuito. Não é computável para aposentadoria.

Ofício-Parecer 1-261/74 (Consultoria-Geral da República)

Diário Oficial de $28 / 2 / 74$, pág. 2.214

- Transformação de função gratificada em cargo em comissão guardando as mesmas características. Contagem de tempo.

A continuidade de exercício após a transformação assegura ao ocupante a contagem do tempo anterior para efeito de aposentadoria, nos termos do art. 180 do Estatuto dos Funcionários, com as vantagens do cargo em comissão em que aquela se transformou.

Processo n. 595/74 (Consultoria Jurídica do DASP)

Diário Oficial de $26 / 3 / 74$, pág. 3.370

\section{TRANSFERENCIA}

— Instruções Normativas, no interesse da uniformidade, na execução dos atos delegados no Decreto $n .^{\circ} 73.987 / 74$, relativamente a:

1 - Requisitos a serem preenchidos nos processos referentes aos atos delegados;

II - Modelos de portarias a serem adotados na expedição de atos delegados.

Portaria n: 94, de $1 / 5 / 74$ (DG-DASP)

Diário Oficial de $13 / 5 / 74$

(Ver Portaria n. $103 / 74-$ D.O. de $21 / 5 / 74$ )

\section{TRIBUNAL DE CONTAS DA UNIÃO}

- Reajusta os vencimentos e salários dos servidores da Secretaria-Geral do Tribunal de Contas da Uniăo e dá outras providências.

Decreto-lei n. 1.318 , de $12 / 3 / 74$

Diário Oficial de $13 / 3 / 74$, capa

Aprovado pelo Decreto Legislativo n: $32 / 74$

R. Serv. públ., Brasília, 109 (3) jul./set. 1974 


\section{IRIBUNAL DE CONTAS DO DISTRITO FEDERAL}

- Reajusta os vencimentos e salários dos servidores dos Serviços Auxiliares do Tribunal de Contas do Distrito Federal e dá outras providências.

Decreto-lei $n:^{\circ} 1.320$, de $12 / 3 / 74$

Diário Oficial de $13 / 3 / 74$, pág. 2.771

Aprovado pelo Decreto Legislativo $n \cdot{ }^{\circ} 35 / 74$

\section{TRIBUNAL FEDERAL DE RECURSOS}

- Reajusta os vencimentos, proventos e salários dos servidores das Secretarias do Tribunal Federal de Recursos e do Conselho da Justiça Federal e dá outras providências.

Decreto-lei n. 1.326 , de $30 / 4 / 74$

Diário Oficial de $2 / 5 / 74$, pág. 5.037

Republicado no Diário Oficial de $10 / 5 / 74$

Aprovado pelo Decreto Legislativo n. $48 / 74$

\section{TRIBUNAL DE JUSTIÇA DO DISTRITO FEDERAL}

- Concede aumento de vencimentos e salários dos servidores da Secretaria e dos Serviços Auxiliares do Tribunal de Justiça do Distrito Federal.

Decreto-lei n.: 1.332 , de $5 / 6 / 74$

Diário Oficial de $6 / 6 / 74$, capa

\section{TRIBUNAL REGIONAL ELEITORAL}

- Concede aumento de vencimentos aos funcionários do Tribunal Superior Eleitoral e dos Tribunais Regionais Eleltorais e dá outras providências.

Decreto-lei n. 1.321 , de $13 / 3 / 74$

Diário Oficial de $13 / 3 / 74$, pág. 2,772

Retificado no Diário Oficial de $27 / 3 / 74$

Aprovado pelo Decreto Legislativo n. $37 / 74$

\section{TRIBUNAL REGIONAL. DO TRABALHO}

- Reajusta os vencimentos e salários dos servidores das Secretarias dos Tribunais Regionais do Trabalho, e dá outras providências.

Decreto-Lei n. 1.333 , de $6 / 6 / 74$

Diário Oficial de $7 / 6 / 74$, capa

R. Serv. públ., Brasilia, 109 (3) Jul./set. 1974 


\section{TRIBUNAL SUPERIOR ELEITORAL}

- Concede aumento de vencimentos aos funcionários do Tribunal Superior Eleitoral e dos Tribunais Regionais Eleitorais e dá outras providências.

Decreto-lei n. 1.321 , de $13 / 3 / 74$

Diário Oficial de $13 / 3 / 74$, pág. 2.772

Retificado no Diário Oficial de $27 / 3 / 74$

Aprovado pelo Decreto Legislativo n: $37 / 74$

\section{VALORES DE VENCIMENTOS}

- Aprova as tabelas de valores e cálculos de despesa de administração de pessoal do Serviço Civil do Poder Executivo, relativamente a níveis, símbolos, vencimentos e gratificações - adicional, de tempo integral, de serviço extraordinário e de representação de gabinete, assim como a descontos para o IPASE, que vigorarão a partir de $1^{\circ}$ março de 1974 , ex-ví do que dispõe o artigo 13 do Decreto-lei $n .^{\circ} 1.313 / 74$.

Portaria n.: 27, de 5/3/74 (DG-DASP)

Diário Oficial de $11 / 3 / 74$, pág. 2.599

Retificado no Diário Oficial de $13 / 3 / 74$, pág. 2.807

\section{VIAGENS AO EXTERIOR}

- Faz recomendações quanto a viagens ao exterior de funcionários ou empregados de todos os escalões da administração direta e indireta bem como das Fundações sob supervisão ministerial.

Circular da P.R. n. 3 , de $5 / 6 / 74$

Diário Oficial de $5 / 6 / 74$, pág. 6.423

- Dispõe sobre viagens ao exterior, a serviço ou com o fim de aperfeiçoamento sem nomeação ou designação, e dá outras providências. (Revoga os decretos n. s $61.775 / 67$ e $67.494 / 70$ ).

Decreto n. 74.143 , de $4 / 6 / 74$

Diário Oficial de $4 / 6 / 74$, capa

Retificado no Diário Oficial de $14 / 6 / 74$

R. Serv, públ., Brasilia, 109 (3) jul./set. 1974 


\section{VENCIMENTOS}

- Reajusta os vencimentos e salários dos servidores do Poder Executivo e dá outras providências.

Decreto-lei n. 1.313 , de 28/2/74

Diário Oficial de $28 / 2 / 74$, capa

(Aprovado pelo Decreto Legislativo n.: 29/74)

- Reajusta os vencimentos e salários dos servidores da Secretaria-Geral do Tribunal de Contas da União e dá outras providências.

Decreto-lei n. 1.318 , de $12 / 3 / 74$

Diário Oficial de $13 / 3 / 74$, capa

Aprovado pelo Decreto Legislativo n. $32 / 74$

- Reajusta os vencimentos dos servidores do Distrito Federal e dá outras providências.

Decreto-lei n. 1.319 , de $12 / 3 / 74$

Diário Oficial de $13 / 3 / 74$, capa

Aprovado pelo Decreto Legislativo n. $38 / 74$

- Reajusta os vencimentos e salários dos servidores dos Serviços Auxiliares do Tribunal de Contas do Distrito Federal e dá outras providências.

Decreto-lei n. 1.320 , de $12 / 3 / 74$

Diário Oficial de $13 / 3 / 74$, pág. 2.771

Aprovado pelo Decreto Legislativo n. $35 / 74$

- Concede aumento de vencimentos aos funcionários do Tribunal Superior Eleitoral e dos Tribunais Regionais Eleitorais e dá outras providências.

Decreto-lei n. 1.321, de 13/3/74

Diário Oficial de $13 / 3 / 74$, pág. 2.772

Aprovado pelo Decreto Legislativo $n 0^{\circ} 37 / 74$

- Concede aumento de vencimentos e salários aos servidores das Secreta. rias do Superior Tribunal Militar e das Auditorias da Justiça Militar e dá outras providências.

Decreto-lei n: 1.324, de 16/4/74

Diário Oficial de $16 / 4 / 74$, capa

Aprovado pelo Decreto Legislativo n. $44 / 74$

R. Serv. públ., Brasilia, 109 (3) jul./set. 1974 
- Reajusta os vencimentos, proventos e salários dos servidores das Secretarias do Tribunal Federal de Recursos e do Conselho da Justiça Federal e dá outras providências.

Decreto-lei n. 1.326 , de $30 / 4 / 74$

Diário Oficial de $2 / 5 / 74$, pág. 5.037

Republicado no Diário Oficial de $10 / 5 / 74$

Aprovado pelo Decreto Legislativo n. $48 / 74$

- Reajusta os vencimentos e salários da Justiça Federal de Primeira Instância e dá outras providências.

Decreto-lei n. 1.327 , de $3 / 5 / 74$

Diário Oficial de $6 / 5 / 74$, capa

Aprovado pelo Decreto Legislativo n. $47 / 74$

- Concede aumento de vencimentos e salários aos servidores da Secretaria e dos Serviços Auxiliares do Tribunal de Justiça do Distrito Federal.

Decreto-lei n. 1.332 , de $5 / 6 / 74$

Diário Oficial de $6 / 6 / 74$, capa

- Reajusta os vencimentos e salários dos servidores das Secretarias dos Tribunais do Trabalho, e dá outras providências.

Decreto-lei n. 1.333 , de $6 / 6 / 74$

Diário Oficial de $7 / 6 / 74$, capa

- Opção pelo vencimento assegurada no art. $4 .^{\circ}$ da Lei n..$^{\circ}$ 5.843, de 1972. Interpretação.

A opção pelo vencimento ou salário do cargo ou emprego, ali assegurada, abrange todas as vantagens pecuniárias correspondentes às funções exercidas no órgão de origem. Os conceitos de vencimentos e salários são os entendidos em acepção ampla.

Ofício-Parecer J-001/74 (Consultoria-Geral da República)

Diário Oficial de $29 / 3 / 74$, pág. 3.548 